\title{
SODIUM MOVEMENT ACROSS THE BLOOD-BRAIN BARRIER IN NEWBORN AND ADULT RATS AND ITS AUTORADIOGRAPHIC LOCALIZATION*
}

\author{
DOROTHY S. LUCIANO \\ Department of Physiology, University of Michigan, Ann Arbor, Mich. (U.S.A.)
}

(Accepted February 6th, 1968)

INTRODUCTION

The rate of movement of sodium from plasma to brain and its final steady state distribution are affected by the blood-brain barrier phenomena. There is, however, only one report comparing sodium movement across the blood-brain barrier in newborn and adult animals. Bakay ${ }^{2}$ noticed that the brains of 4 fetal kittens contained about twice as high a concentration of radioactive sodium as did the maternal brain $5 \mathrm{~h}$ after the intravenous injection of ${ }^{24} \mathrm{Na}$ into I pregnant cat.

Some substances such as glutamic acid ${ }^{16}$, cholesterol ${ }^{11}$, lysine ${ }^{20}$, phosphorus ${ }^{1}$, and potassium ${ }^{19}$ have been shown to enter brain more rapidly or have a higher steady state concentration relative to plasma in newborns as compared to adults, i.e, the blood-brain barrier is more 'permeable'. But increased barrier permeability was not found consistently in developmental studies using trypan blue, a dye largely bound to plasma protein ${ }^{15}$.

The access of sodium to the brains of newborn animals is not known despite the importance of this ion in neuron excitability and tissue fluid balance; its effect upon specific enzyme systems in brain ${ }^{26}$; its suggested role in cerebrospinal fluid formation ${ }^{29}$ and its association with states of mental depression ${ }^{7}$ and other neurological symptoms extending from simple headache to delirium, seizures, and death ${ }^{18}$.

With the working hypothesis that barrier data from other substances cannot justifiably be extrapolated to include sodium, experiments were designed to answer the following questions: (1) Is the blood-brain barrier of newborn animals more permeable to sodium than that of adults as measured by whole brain uptake?; (2) Since the brain is not homogeneous, are the anatomical areas of increased permeability similar in adult and newborn animals as measured by autoradiography?

* This article is based upon a dissertation submitted in partial fulfilment of the requirements for the degree of Doctor of Philosophy in the University of Michigan.

Brain Research, 9 (1968) 334-350 
METHODS

Animals. Albino rats over 3 months of age and of either sex were obtained from Spartan Research Animals, Inc. for the adult data. Pregnant rats in the 15th to 20th day of gestation were obtained from the same supplier, and rats from the ensuing litters were used for the newborn data. All experiments on newborns were completed within $30 \mathrm{~h}$ after birth.

Anesthesia. Animals were anesthetized by intraperitoneal injection of sodium pentobarbital, $35 \mathrm{mg} / \mathrm{kg}$ body weight to the adults, $18-20 \mathrm{mg} / \mathrm{kg}$ body weight to the newborns. Care was taken to assure adequate respiration since the total effects of hypoxia upon the blood-brain barrier in newborn animals are not known. The skin color of the anesthetized animals was compared with that of unanesthetized littermates to determine adequacy of respiration. Unsatisfactory animals were discarded.

Surgicalmethods. The adult rats were injected with isotope intravenously via a cannula in the femoral vein, the newborns via a glass micropipette in the external jugular or femoral vein. The isotope was administered as $0.9 \%\left[{ }^{22} \mathrm{Na}\right]$ sodium chloride (Abbott Laboratories, activity approximately $25 \mu \mathrm{C} / \mathrm{ml}$ ) in less than 1 min in the dose of $50 \mu \mathrm{C} /$ $\mathrm{kg}$ for adults and approximately $190 \mu \mathrm{C} / \mathrm{kg}$ for newborns. The volumes injected, as percentages of total blood volume, were about $4 \%$ for adults and $9 \%$ for newborns. The animals were sacrificed in groups of four 15 or $30 \mathrm{~min}$, or 1, 2, or $4 \mathrm{~h}$ after the injection. Four adults and 4 newborns were injected with isotope intraperitoneally and killed $12 \mathrm{~h}$ after the injection.

At the time of sacrifice, the chest cavity of the anesthetized animal was opened, the large thoracic vessels were cut, and blood was collected into heparinized capillary tubes. Blood was drained from the cranial vessels for $15-20 \mathrm{sec}$ and, within $30 \mathrm{sec}$ from opening the thoracic cavity, the entire carcass was frozen in liquid nitrogen. The center of the cerebral hemispheres froze within $1 \mathrm{~min}^{13}$. After $5-10 \mathrm{~min}$ the carcass was removed and transferred to a deep freeze for storage at $-15^{\circ} \mathrm{C}$. Within 24 h the entire brain back to the caudal regions of the medulla and excluding the olfactory bulbs was removed from the cranium.

Analytical methods. The blood sample was centrifuged within $45 \mathrm{~min}$, and 50 or $100 \mu 1$ of plasma were drawn off. The plasma sodium was determined in an internal standard flame photometer, and the radioactivity of the same sample was determined in a scintillation well counter to obtain the specific activity of plasma in counts/min per requiv $\mathrm{Na}^{+}$.

The whole brain was weighed, dried in an oven at $105^{\circ} \mathrm{C}$ to constant weight, and reweighed to give tissue water. Concentrated nitric acid was added, and the tissue was digested at $200^{\circ} \mathrm{C}$ for $1 \mathrm{~h}$. Concentrated formic acid (to neutralize the solution) and $\mathrm{Li}_{2} \mathrm{SO}_{4}$ were added. The solution was left overnight to allow maximum leaching of sodium from the remaining tissue fragments and then filtered. The total sodium and radioactivity of the filtrate were determined to obtain the specific activity of brain in counts/min per $\mu$ equiv total $\mathrm{Na}^{+}$. The accuracy of the flame photometer was checked by adding known amounts of sodium to some of the brain samples.

The ratio specific activity of brain/specific activity of plasma was determined for 
each animal, and the mean of the four ratios for each adult group was compared statistically to the mean of the newborn group that was sacrificed after the same time interval.

Anesthesia control. The effect of sodium pentobarbital on the permeability of the blood-brain barrier is not known, so control experiments were done on both newborn and adult rats.

Three newborn littermates were given an intraperitoneal injection of $35 \mathrm{mg} / \mathrm{kg}$ sodium pentobarbital plus $50 \mu \mathrm{C} / \mathrm{kg} 0.9 \%$ [ ${ }^{22} \mathrm{Na}$ ] sodium chloride; 4 others from the same litter were given radioactive saline alone. After $90 \mathrm{~min}$ specific activity ratios were determined (Table I).

Similar experiments were done on adults except that the isotope was given through intravenous cannulas implanted 3 days previously. The anesthesia was given intraperitoneally, and the animals were killed at $1 \mathrm{~h}$ (Table I).

The ratios specific activity of brain/specific activity of plasma of anesthetized and unanesthetized rats are not significantly different regardless of the age of the animals.

Autoradiography. Animals were prepared for the autoradiographic studies with identical surgical procedures and they were frozen 15 min after the injection. After the brain was removed from the cranium, $16-48 \mu$ tissue sections were cut in a cryostat at $-10^{\circ} \mathrm{C}$, placed on glass slides, stored over formalin for $24 \mathrm{~h}$ for vapor fixation, apposed to Kodak NTB-3 autoradiographic film plates, and stored with desiccant in a lightand moisture-proof box for exposure. After a 3-6 week exposure period at $-4^{\circ} \mathrm{C}$, the plates were developed. At no time between the freezing of the brain and the end of the exposure period were the brains or tissue sections seen to thaw.

TABLE I

THE EFFECT OF SODIUM PENTOBARBITAL ON THE PERMEABILITY OF THF, BLOOD-BRAIN BARRIER IN NEWBORN AND ADULT RATS

\begin{tabular}{lll}
\hline & \multicolumn{2}{c}{ Specific activity brain/specific activity plasma } \\
\cline { 2 - 2 } Anesthetized & Unanesthetized ${ }^{* *}$ \\
\hline Newborn & 0.715 & 0.662 \\
& 0.727 & 0.703 \\
& 0.695 & 0.777 \\
Mean & & 0.665 \\
Standard deviation & 0.712 & 0.702 \\
& \pm .016 & 0.053 \\
Adult & 0.669 & 0.531 \\
& 0.707 & 0.735 \\
& 0.669 & 0.661 \\
Mean & 0.664 & 0.697 \\
Standard deviation & 0.677 & 0.656 \\
& 0.020 & \pm 0.089
\end{tabular}

* Intraperitoneal injection of $35 \mathrm{mg} / \mathrm{kg}$ sodium pentobarbital plus $50 \mu \mathrm{C} / \mathrm{kg} 0.9 \%$ [22 Na]sodium chloride.

** Radioactive saline alone.

Brain Research, 9 (1968) 334-350 
Autoradiographic resolution was determined by measuring (a) the smallest distance between two ${ }^{22} \mathrm{Na}$-liquid platinum lines that could be distinguished autoradiographically and (b) anatomical features such as the choroid plexuses and ventricles. The resolution was better than $0.2 \mathrm{~mm}$. The contrast in the autoradiographic images was enhanced in the photographic records. The film used does not allow direct counts for simple quantification, and the method was not calibrated.

Control experiments in which brain tissue slices from non-injected rats were apposed to autoradiographic film plates, exposed and developed showed no image artifact from chemical exposure of the film.

\section{Discussion of Methods}

(1) The direct entry of sodium into brain tissue could not be distinguished from the passage from plasma into CSF (cerebrospinal fluid) or from CSF into brain. The term 'blood-brain barrier' will therefore be used to include all three barrier sites.

(2) The experimental design does not provide information about the mechanism of the barrier to sodium in either adult or newborn animals.

(3) Contamination of the brain sample by residual blood is particularly serious during the early time intervals when the plasma specific activity is high and brain specific activity is low. Draining the head reduces the blood content to about $1.5 \%$ (ref. 10). The maximal error in brain specific activity that could be caused by residual blood in either adult or newborn brain at $15 \mathrm{~min}$ would be about $3 \%$. The tissue sections were examined microscopically, and there was no consistent correlation between the rare sites of pooled blood and autoradiographic density.

(4) Exposure of brain and ischemia can affect the movement of ions ${ }^{17}$. These were avoided by freezing the animal before opening the skull. Assuming a diffusion constant of $8.0 \cdot 10^{-4} \mathrm{sq} . \mathrm{cm} / \mathrm{min}$ through a cortex containing spherical cells $\mathrm{s}^{22}$, it is possible to calculate the distance from the in vivo source at which the concentration of diffusing ${ }^{22} \mathrm{Na}$ would equal one-half the original concentration. This distance at most would be $0.3 \mathrm{~mm}$ in the 90 -sec period between killing the animal and freezing the brain.

(5) Several possibilities must be considered in the interpretation of autoradiographic patterns: (a) the experimental methods are adequate and heterogeneity truly reflects areas of varying permeability; (b) heterogeneity is present but is due to sodium binding or variations in total sodium concentration throughout the brain; (c) no binding occurs, but isotope diffuses from its in vivo location during exposure of the autoradiograms and any real heterogeneity is obliterated (sodium diffusion must be considered since the temperatures during tissue preparation and autoradiographic exposure were higher than the estimated eutectic point of tissue); (d) both diffusion during exposure and binding occur and heterogeneity is, at least in part, an artifact.

These can be resolved by comparing autoradiograms of the brains of rats killed 15 min after the isotope injection with those of animals killed after longer time intervals $(2.5,3,5$ or $24 \mathrm{~h})$ providing that the exposure time of the '15-min interval' autoradiograms is equal to or longer than that of the 'long interval' autoradiograms. The results are summarized in Table II. 
TABLE II

COMPARISON OF RESULTS OF 'SHORT INTERVAL' AND 'LONG INTERVAL' AUTORADIOGRAMS

\begin{tabular}{|c|c|c|c|}
\hline \multicolumn{2}{|c|}{ Possibility } & \multirow{2}{*}{$\begin{array}{l}\text { 15-min interval results } \\
\text { heterogeneity or } \\
\text { homogeneity }\end{array}$} & \multirow{2}{*}{$\begin{array}{l}\text { Long interval results } \\
\text { homogeneity }\end{array}$} \\
\hline (a) & Method satisfactory & & \\
\hline (b) & $\begin{array}{l}\text { Binding but no diffusion } \\
\text { during exposure }\end{array}$ & ? heterogeneity & $\leqq$ heterogeneity \\
\hline (c) & $\begin{array}{l}\text { Diffusion during exposure } \\
\text { but no binding }\end{array}$ & homogeneity & $=$ homogeneity \\
\hline (d) & $\begin{array}{l}\text { Diffusion during exposure } \\
\text { and binding }\end{array}$ & heterogeneity & $=:-$ heterogeneity \\
\hline
\end{tabular}

TABLE III

PLASMA SODIUM, BRAIN WATER AND BRAIN SODIUM IN ADULT AND NEWBORN RATS

\begin{tabular}{|c|c|c|c|c|}
\hline & \multirow{2}{*}{$\begin{array}{l}\text { Plasma } \mathrm{Na}^{+} \\
\text {(mequiv/l) }\end{array}$} & \multirow{2}{*}{$\begin{array}{l}\text { Brain water } \\
(\%)\end{array}$} & \multicolumn{2}{|l|}{ Total brain $\mathrm{Na}^{+}$} \\
\hline & & & mequiv $/ \mathrm{kg}$ wet wt. & mequiv/kg tissue $\mathrm{H}_{2} \mathrm{O}$ \\
\hline \multicolumn{5}{|c|}{ Adult rats } \\
\hline$n$ & 22 & 22 & 22 & 22 \\
\hline$\ddot{x}$ & 139 & 78.8 & 47 & 60 \\
\hline S.D. & \pm 3 & \pm 0.6 & 2 & \pm 3 \\
\hline S.E. & \pm 1 & \pm 0.1 & \pm 1 & \pm 1 \\
\hline \multicolumn{5}{|c|}{ Newborn rats } \\
\hline$n$ & 38 & 42 & 42 & 42 \\
\hline $\bar{x}$ & 141 & 88.8 & 71 & 80 \\
\hline S.D. & \pm 5 & \pm 1.6 & -4 & \pm 4 \\
\hline S.E. & \pm 1 & \pm 0.3 & \pm 1 & \pm 1 \\
\hline
\end{tabular}

$n=$ number of animals; $\bar{x}=$ mean; S.D. $\cdots$ standard deviation; S.E. $=$ standard error of the mean.

The autoradiograms at 15-min intervals did show either homogeneity or heterogeneity (see Results). Autoradiograms from animals with longer intervals after the injection were always homogeneous. Therefore, significant binding and/or diffusion do not occur and the methods of autoradiographic localization are acceptable.

RESULTS

Plasma sodium, brain sodium, and brain water of adult and newborn rats

The total sodium of brain and plasma and the brain water of the adult and the newborn rats used in these experiments are listed in Table III. Comparison of the adult data with the newborn data shows: (1) the plasma sodium values of the two groups are not significantly different; (2) the percent water in newborn rat brain is significantly 


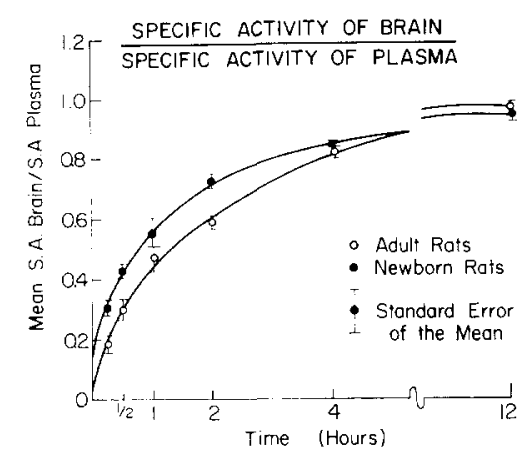

Fig. 1. Mean specific activity of brain/specific activity of plasma versus time of adult and newborn rats.

greater than in adult rat brain $(P<0.01)$; and (3) the total sodium of newborn rat brain is significantly higher than that of the adult $(P<0.001)$ expressed as either mequiv $\mathrm{Na}^{+} / \mathrm{kg}$ wet weight or as mequiv $\mathrm{Na}^{+} / \mathrm{kg}$ tissue water. Therefore, the increase in tissue water of newborn rat brain cannot alone account for the increase in total brain sodium.

Variation in brain sodium in the first 24 hours after birth

Much of the variation in the data collected from newborn rats appears to be related to the animals' precise ages. In thirteen 2 -h-old rats from 4 litters plasma sodium was $141 \pm 1$ mequiv $/ 1$, brain water was $89.2 \pm 0.2 \%$, and total brain sodium $75 \div 1$ mequiv $/ \mathrm{kg}$ wet weight. Numbers represent the mean \pm standard error of the mean. Fifteen 24 -h-old rats from 4 litters had $142 \pm 1$ mequiv/l plasma sodium, $88.9 \pm 0.2 \%$ brain water and $72 \pm 1$ mequiv $/ \mathrm{kg}$ wet weight total brain sodium. There was no significant difference between the plasma sodium or brain water values of these two groups, but the brain sodium did decrease significantly $(P<0.03)$ during this $22-\mathrm{h}$ period.

\section{Sodium entry into brain}

The two curves of the ratio brain specific activity/plasma specific activity versus time (Fig. 1) depict sodium entry into adult and newborn brain. Although both tissues reach the final ratio of 0.95 at $12 \mathrm{~h}$, the ratios of newborn and adult brains at the early time intervals are significantly different (see Table IV).

\section{Autoradiography of adult rat brains}

Satisfactory autoradiograms were obtained from 4 adult and 2 newborn brains. Most results mentioned below were seen in at least 2 brains.

One area of adult brain consistently indicated increased uptake of ${ }^{22} \mathrm{Na}$. This was a transverse band across dorsal medulla and ventral cerebellum that first appeared 1.4 


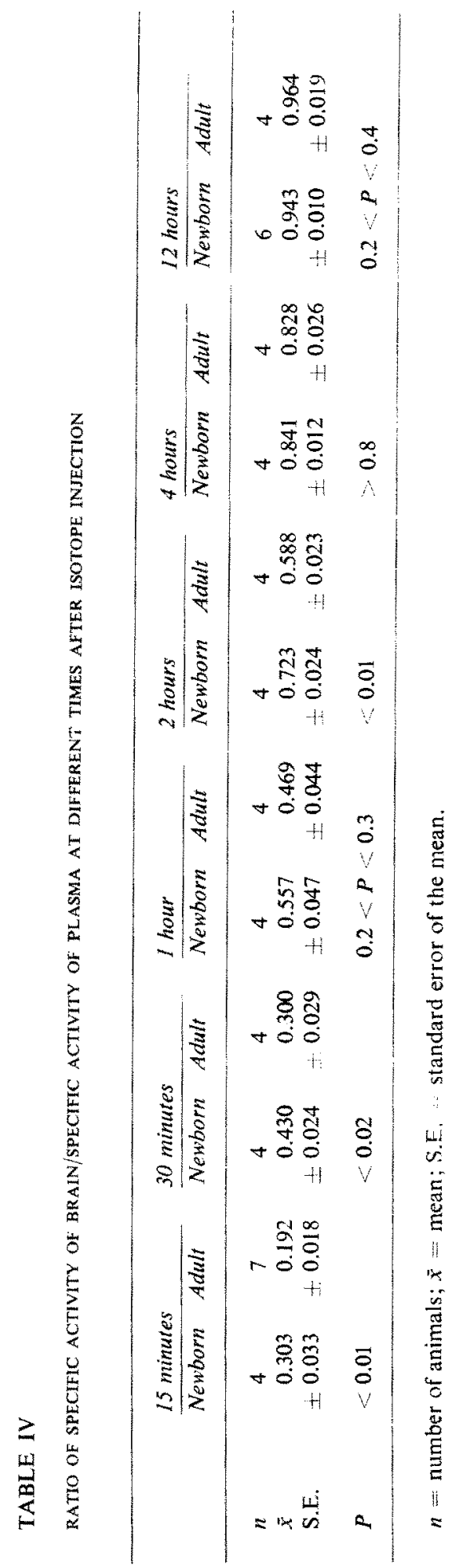

Brain Research, 9 (1968) 334-350 


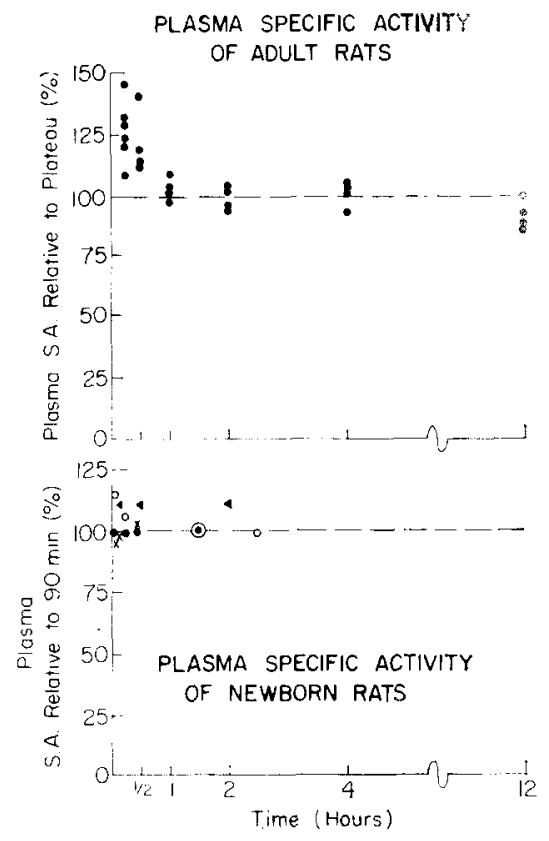

Fig. 2. Plasma specific activity of adults (top) and newborns (bottom) at different times after injection relative to plateau or $90 \mathrm{~min}$ value (see text). Each newborn animal is represented by a separate symbol.

$\mathrm{mm}$ anterior to the foramen of Luschka and extended caudally past the obex, reaching its maximum width and autoradiographic density at the level of the foramen of Luschka (Fig. 3).

Adult white matter sometimes showed increased uptake of sodium. This was seen most often in the corpus callosum (Figs. 4-7), but it was also seen occasionally in the subcortical white matter, radiations of the internal capsule, external capsule, fimbria and alveus of the hippocampus, stria medullaris (Fig. 5), anterior commissure (Figs. 4, 6), optic tract (Fig. 7), and fasciculus retroflexus.

There were also indications of increased sodium uptake in adult brain by the lateral walls of the posterior portion of the third ventricle, the medial portion of the posterior thalamus (Fig. 8), the granular and medullary layers of the cerebellum (Fig. 9), and the septal region (Figs. 4, 11 ).

Attempts were made to examine those areas of adult brain that normally allow greater entry of plasma substances (area postrema, infundibulum, etc.). The regions of the area postrema (Fig. 10) and subfornical organ (intercolumnar tubercle) (Fig. 11) showed increased uptake, but the density in these areas was neither greatest at these specific structures nor restricted to them. The marked increase in uptake in the septal region of one brain was not repeated in similar sections in a second animal. The choroid plexuses in some autoradiograms appeared to have an increased concentration of isotope (Fig. 11). The uptake by the subcommissural organ was not isolated but was included in the band that lined the third ventricle. Satisfactory sections of the pineal body, infundibulum and hypophysis were not obtained in adult rat. 

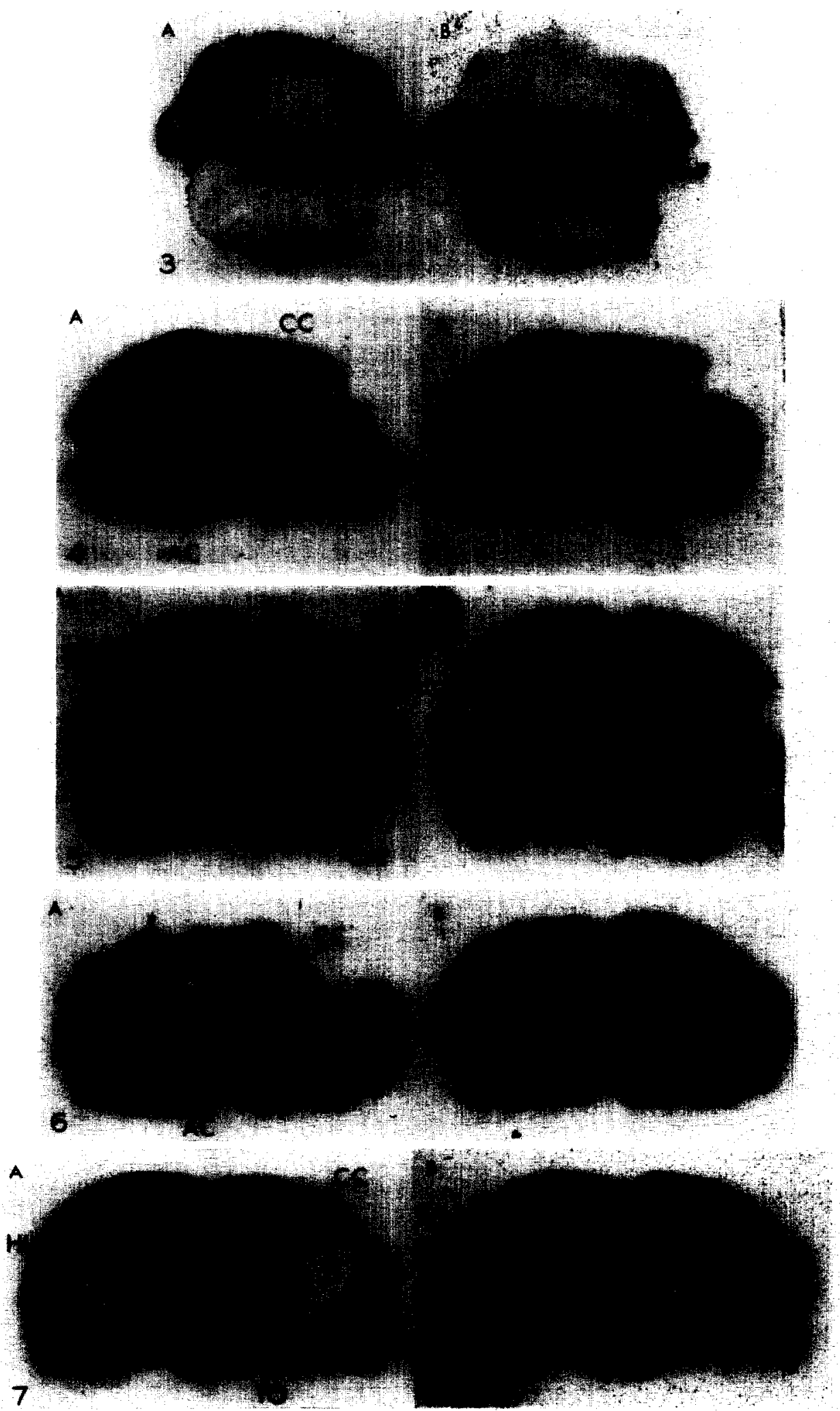
Autoradiography of newborn rat brains

The site of greatest sodium uptake in newborn rat brains was the proliferative cell zone (periependymal matrix cells). The autoradiographic density was so great and so specific that the entire area could be traced as clearly on the autoradiograms as on the stained tissue sactions.

The anterior limit of this structure was in the olfactory bulb where the greatest number of proliferative cells and the greatest autoradiographic density were lateral to the olfactory ventricle (Fig. 12). The zone continued caudally and then began to extend dorsally mainly along the lateral edge of the lateral ventricle (Fig. 13). It spread even more dorsolateralward, passing around the most lateral portion of the lateral ventricle (Fig. 14), and then continued posteromedially as a small band lining the ventricle in the subcortical white matter in the region of the cingulum. Traces of this cell zone could be seen in the medial portions of the subcortical white matter in sections posterior to the pineal body. All regions of the proliferative cell zone took up increased amounts of radioactive sodium or took it up at a faster rate than did other regions of newborn brain. While the autoradiograms of newborn cerebellum were technically unsatisfactory, the proliferative cell zone (external granule layer) here, too, indicated increased density, supporting the above statement.

Layers of cell bodies in Ammon's horn and the dentate gyrus clearly indicated increased sodium uptake in newborn brain (Figs. 14, 15) although this was never seen in adult brain. Also, in contrast to the adult, newborn white matter showed the least uptake of all regions (Figs. 13-15, 17). The corpus callosum, subcortical white matter and radiations of the internal capsule could sometimes be detected by their absence of autoradiographic density. But since the degree of density of the autoradiographic image is a relative rather than an absolute concept, it is possible that the apparent decreased uptake in white matter merely reflects an increased uptake by the gray.

The pineal body (Fig. 16), subcommissural organ (Fig. 18), and the subfornical organ (Fig. 15) showed increased sodium uptake. There was no apparent increase in

General Legend. Figs. 3 through 18.

(1) Of each pair of photographs, 'A' is the tissue section from which 'B', the autoradiogram, was made.

(2) Movement or folding of the tissue sections may have occurred during staining. The tissues were stained with thionine after exposure of the autoradiographic plates.

(3) If a portion of the tissue section was folded during exposure, the autoradiographic density under the fold would be greater than normal. This artifact is present in most of the autoradiograms, for example, Figs. 13-16.

(4) All sections are approximately coronal.

Fig. 3. Transverse band across dorsal medulla and ventral cerebellum at the level of the foramen of Luschka (adult).

Fig. 4. Corpus callosum (CC), anterior commissure (AC), and septal region (adult).

Fig. 5. White matter in the radiations of the corpus callosum ( $\mathrm{RCC}$ ), internal capsule (CAI), fimbria and alveus of the hippocampus (HI), and stria medullaris (SM) (adult).

Fig. 6. Corpus callosum (CC) and anterior commissure ( $\mathrm{AC}$ ) (adult).

Fig. 7. Corpus callosum (CC), alveus of the hippocampus (HI), and optic tract (TO) (adult). 

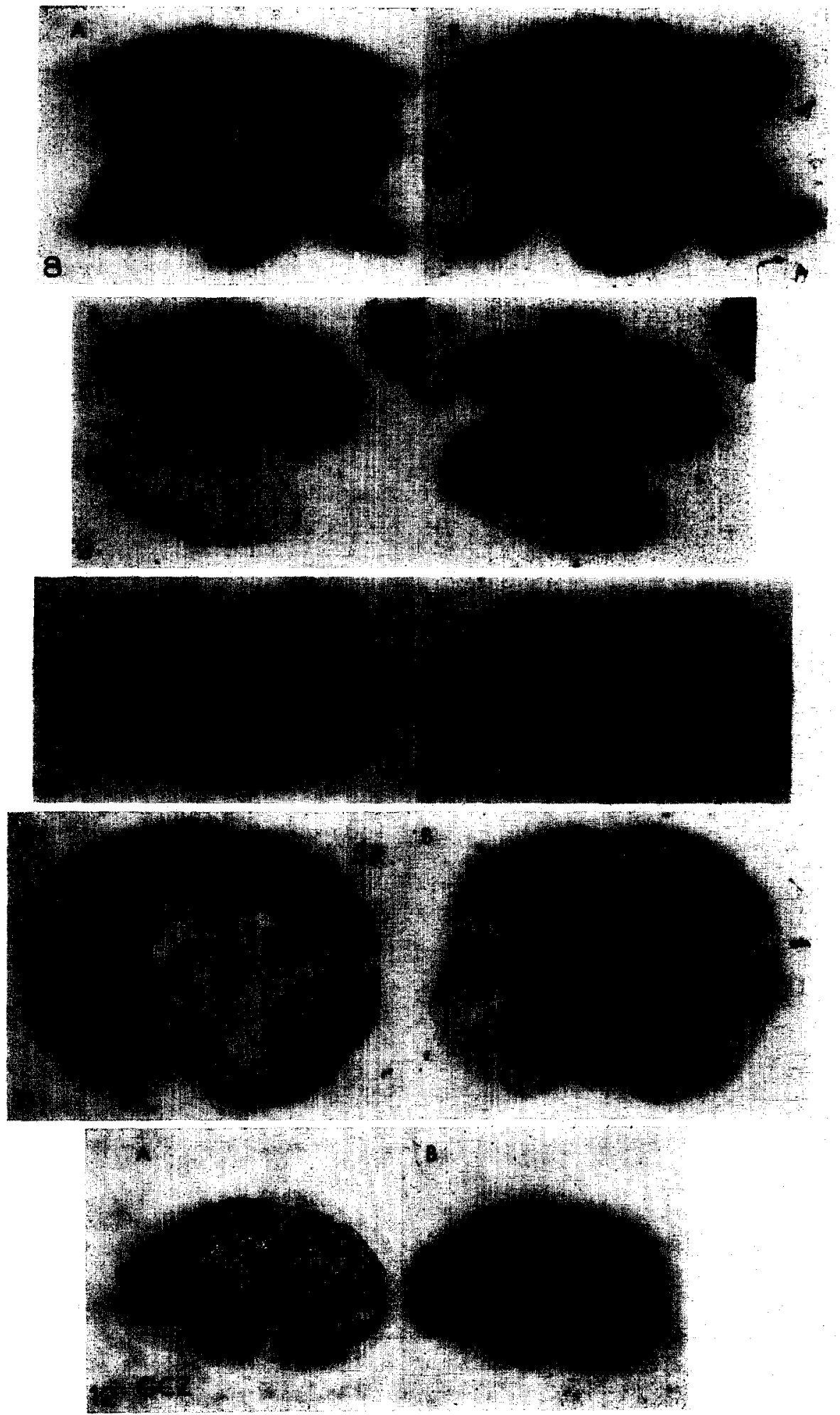

Brain Research, 9 (1968) 334-350 
sodium uptake in the septal region, choroid plexus, or walls of the third ventricle in newborn rat. The sections of brain stem were not good but there were no obvious areas of inhomogeneity.

DISCUSSION

The adult plasma sodium, total brain sodium, and brain water correspond with values presented in the literature 27 . The newborn plasma sodium and brain water values also agree, but the total brain sodium values in my experiments are markedly higher than other published data on 1-day-old rats ( 71 versus 56 mequiv $\mathrm{Na}^{+} / \mathrm{kg}$ wet wt. $)^{30}$. The tissue samples of Vernadakis and Woodbury ${ }^{30}$ did not contain the germinal cell zone or any other subcortical areas, and this may explain the discrepancy in our results.

Sodium entered adult brain with a half-time of about $75 \mathrm{~min}$ and newborn brain with a half-time of about $40 \mathrm{~min}$ (Fig. 1) after a single intravenous injection. Olson and Rudolph $^{24}$ found that sodium entered the CSF of dogs after intravenous injection with a half-time of $99 \mathrm{~min}$, and the sodium that did enter CSF equilibrated rapidly with brain. From Davson's ${ }^{9}$ published rate constant for the entry of sodium into the CSF of rabbits undergoing constant infusion, a half-time of $95 \mathrm{~min}$ can be calculated. Woodbury $^{33}$ found a half-time of total sodium entry into rat brain of about 80 min after intraperitoneal injection. These values are surprisingly consistent considering the different animal species, experimental techniques, and analytical methods that were used. No quantitative studies have been reported on the rate of sodium entry into newborn brain.

To justify the interpretation of the data that the rate of entry of sodium into newborn brain is significantly faster than the entry into adult brain, the plasma specific activity levels throughout the experiment must be examined. If the history of the plasma specific activity relative to the sample point were lower in the adult rats, there would have been a smaller concentration force to drive the isotope from plasma to brain, and one would expect the amount of ${ }^{22} \mathrm{Na}$ in adult brain to be lower. In this case, the decreased rate of uptake would not be due to decreased permeability but rather to a decreased concentration gradient. But the history of adult plasma specific activity was higher than that of the newborn rats (Fig. 2).

The plasma specific activity of the adult rats reached a plateau at 402 counts/ min per mequiv $\mathrm{Na}^{+}$(mean of the 1,2 , and $4 \mathrm{~h}$ plasma specific activity values). If this

Fig. 8. Lateral walls of the third ventricle and choroid plexus (adult).

Fig. 9. Granular and medullary layers of cerebellum. The dimensions of the medullary layers are close to the limits of the autoradiographic resolution, but they do appear to take up increased amounts of sodium (adult).

Fig. 10. Area postrema (AP) (adult).

Fig. 11. Septal region (SR) near the subfornical organ (intercolumnar tubercle) and anterior commissure $(\mathrm{AC})$ (adult).

Fig. 12. Germinal cell zone (GCZ) in the olfactory bulb (newborn). 

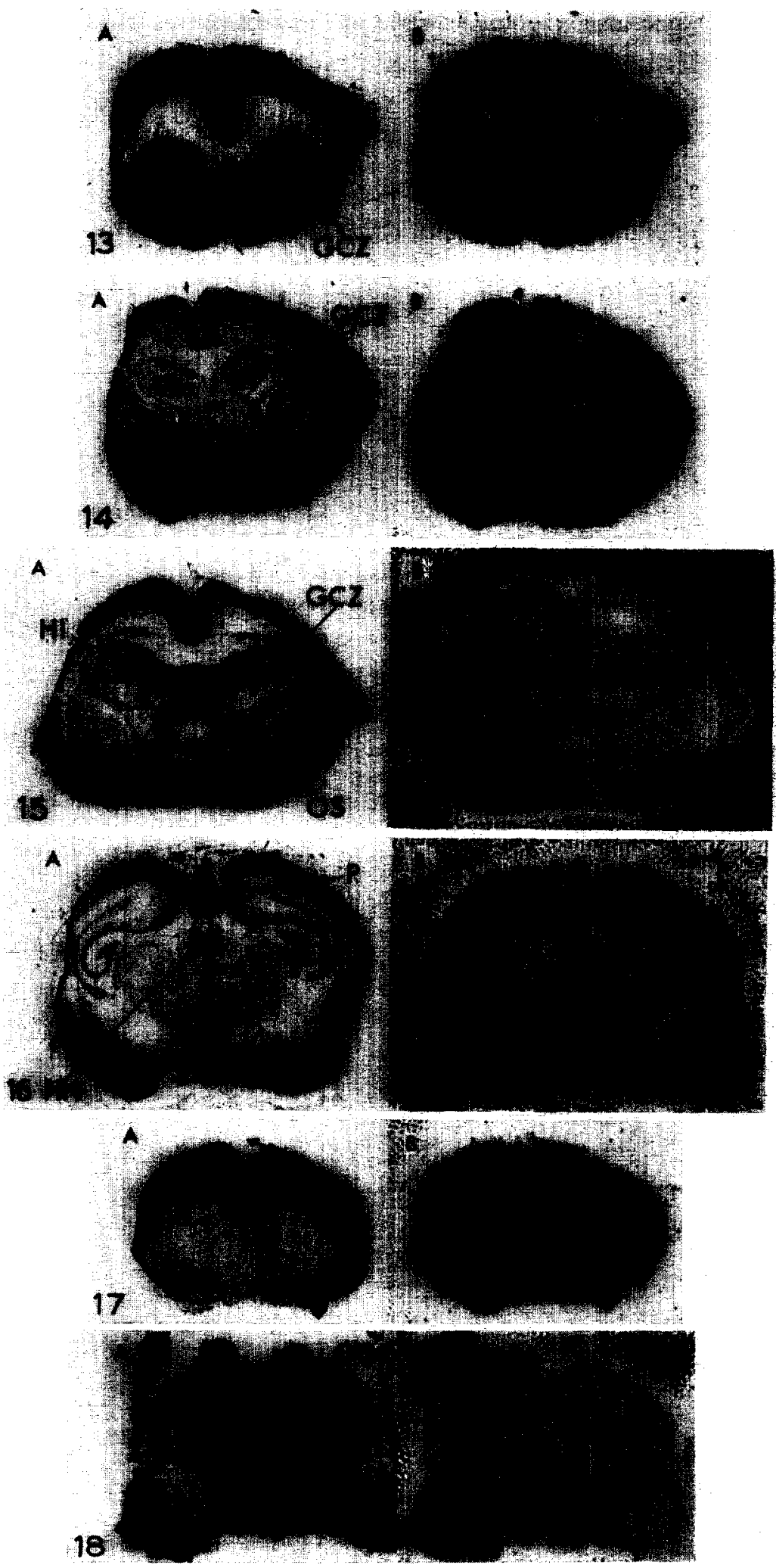
plateau is called the $100 \%$ level, the mean plasma specific activity 15 min after the injection is $125 \%$, at $30 \mathrm{~min}$ is $120 \%$, and within $1 \mathrm{~h}$ it has reached plateau level (Fig. 2 , top).

All newborn rats did not receive the same dose of isotope, and the plasma specific activity values could not be compared directly. Instead, several samples were obtained from each animal. The plasma specific activity values at $90 \mathrm{~min}$ were called $100 \%$, and all other specific activities were plotted relative to that value (Fig. 2, bottom). The mean newborn plasma specific activity was $106 \% 5 \mathrm{~min}$ after the injection. Thus, the newborn relative plasma specific activity is equal to or lower than that of the adult rats, and the greater rate of sodium entry into newborn rats is not due to a history of a high plasma radioactivity.

As striking as the difference in rate of sodium uptake between newborn and adult brain, was the heterogeneous pattern of this uptake. This heterogeneity was particularly impressive since the tracer was sodium, an ion usually characterized by its lack of specificity. In newborn brain the regions of greatest autoradiographic density seem to fall into three, not mutually exclusive, categories: (1) areas of high cell density as the germinal cell zone, pineal body, and subfornical organ; (2) areas of high neuron density as cortex, Ammon's horn, dentate gyrus, and habenular nucleus: (3) cell populations with high nuclear to cytoplasmic volume ratios as the germinal cell zone. One can only speculate on the reasons for these differences between adult and newborn brain since data on the intracellular sodium concentration, permeability of cell membranes to sodium, and $\mathrm{Na}^{+}-\mathrm{K}^{+}$-stimulated ATPase activity per unit of cell membrane are not available.

In both newborn and adult brain, however, several other possibilities must be considered.

(1) Capillary structure. Blood-brain barrier properties have been attributed to the pericapillary basement membrane and glial sheath. The developmental data in the rat are consistent with this view since at birth, when the basement membrane is thinner and less dense and the sheath of cell processes is incomplete ${ }^{12}$, sodium does enter the brain more rapidly. The heterogeneity of uptake might be related to varying rates of maturation of the capillary complex such as those found between spinal cord ${ }^{25}$ and cerebral cortex ${ }^{12}$ but complete anatomical data are not available. However, increased sodium uptake was not restricted to those areas of adult brain in which connective tissue spaces rather than glial processes surround the capillaries (area postrema, subcommissural organ, and subfornical organ) ${ }^{32}$.

Fig. 13. Germinal cell zone (GCZ) passing dorsally and laterally (newborn).

Fig. 14. Germinal cell zone ( $\mathrm{GCZ}$ ), as it passes around the most lateral portion of the lateral ventricle (newborn).

Fig. 15. Germinal cell zone (GCZ), cell layers of Ammon's horn and the dentate gyrus of the hippocampus (HI), and the subfornical organ (OS) (newborn).

Fig. 16. Pineal body (P) and habenular nuclei (HN) (newborn).

Fig. 17. White and gray matter (newborn).

Fig. 18. Subcommissural organ (OSC) (newborn). 
(2) Capillary density and blood flow. The heterogeneity of sodium uptake may be related to vascularity, but this is not likely. Adult white matter, which usually demonstrated increased uptake autoradiographically, has the lowest vascular density of any brain measured ${ }^{6}$. Newborn brain, which had a greater rate and more marked heterogeneity of sodium uptake, is vascularized less densely and more uniformly than adult $^{8}$. The germinal cell zone which showed such striking sodium uptake is only moderately well vascularized ${ }^{14}$.

(3) Vernadakis and Woodbury ${ }^{31}$ report that the inulin (extracellular) space in rat cortex decreases with maturation, but throughout development the number of small neuronal and glial processes increases and the cell bodies become more dispersed while the intercellular gap has been reported to remain the same ${ }^{12}$. If the number of small processes in a given area increases and the intercellular gap remains the same, the volume of extracellular space within that area would increase. One would expect the concentration of substances such as sodium which are said to be chiefly extracellular to increase also. A geometrically small extracellular space in new borns woulc be compatible with a large sodium concentration only if part of the sodium were intracellular.

Autoradiograms of kitten brain $6 \mathrm{~h}$ after intravenous injection of [ $\left.{ }^{35} \mathrm{~S}\right]$ sulfate showed greater uptake in white matter than in gray. However, in adult cats $1 \mathrm{~h}$ after intravenous $\left[{ }^{35} \mathrm{~S}\right]$ sulfate, the uptake was greater in gray matter ${ }^{4}$. Studies with isoniazid $^{5}$, barbital ${ }^{21}$, phenobarbital, thiopental, and urea ${ }^{28}$ also showed greater uptake in gray matter of adult cat brain.

Bakay ${ }^{2}$ gives both chemical and autoradiographic evidence of greatest sodium uptake by the superficial layers of the cerebral and cerebellar cortex, brain stem, and ventricles of adult cat brain at various times after the intravenous injection of isotopic sodium. My autoradiograms of adult rat brain do not support this since many areas adjacent to the ventricles, choroid plexuses, and brain surfaces did not show increased sodium uptake. Bakay froze the brains by covering the exposed dura with solid $\mathrm{CO}_{2}$. Although exact times are not given, his slower method of freezing a larger brain must have resulted in a greater degree of pressure and anoxic changes than occurred in $\mathrm{my}$ experiments. Kapp and Paulson ${ }^{17}$ recently showed that cerebral anoxia is accompanied by the movement of sodium and CSF into brain. Others, too, have shown that hypoxia in adults leads to changes in extracellular sodium in brain ${ }^{23}$ and hypercapnic hypoxia causes an increase in the cerebral uptake of sodium ${ }^{3}$. Except for this possible difference in anoxia and the obvious differences in species, I cannot explain the contradiction of our results.

It is clear that the rate and degree of entry of each tracer must be understood in terms of the stage of development of the individual brain structures.

SUMMARY

The net rate and structural specificity of ${ }^{22} \mathrm{Na}$ entry into newborn and adult rat brain after intravenous injection were investigated.

After a single injection, the half-time of sodium entry into adult rat brain was

Brain Research, 9 (1968) 334-350 
about $75 \mathrm{~min}$, into newborn brain about $40 \mathrm{~min}$, a difference not related to the history of plasma specific activity.

Autoradiograms were made using Kodak NTB-3 plates 15 min after the intravenous injection of ${ }^{22} \mathrm{Na}$. In the adult rats, areas of increased uptake included a band across dorsal medulla and ventral carebellum at the level of the foramen of Luschka, some white matter, the lateral walls of the posterior portion of the third ventricle, and the granular and medullary layers of the cerebellum. The regions of the subfornical organ (intercolumnar tubercle) and area postrema showed increased uptake, but the density in these areas was neither greatest at these specific structures nor restricted to them.

Autoradiograms of newborn brain showed the greatest sodium uptake in the germinal cell zone (subependymal matrix cells). The neocortex, newly formed cell layers of Ammon's horn and the dentate gyrus, pineal body, and subfornical organ showed increased uptake; but the subcommissural organ did not. The density in the region of the walls of the third ventricle was not consistently increased. Areas destined to be white matter showed the least uptake of all.

The pattern of increased barrier permeability to sodium does not conform to the traditional pattern established by trypan blue.

From these data one can see the importance of considering the blood-brain barrier as unique for each class of tracer substance, age of animal, and structural area of the central nervous system.

\section{ACKNOWLEDGEMENTS}

The patient guidance of Dr. James B. Ranck Jr. is gratefully acknowledged.

This work was supported by Michigan Memorial Phoenix Project No. 300 and National Institutes of Health Grant NB-04352.

\section{REFERENCES}

1 BAKAY, L., Studies on BBB with radioactive phosphorus. III. Embryonic development of the barrier, Arch. Neurol. Psychiat. (Chic.), 70 (1953) 30-39.

2 BAKAY, L., Studies in sodium exchange. Experiments with plasma, cerebrospinal fluid, and normal, injured, and embryonic brain tissue, Neurology (Minneap.), 10 (1960) 564-571.

3 Bakay, L., ANd Bendixen, H. H., Central nervous system vulnerability in hypoxaemic states. Isotope uptake studies. In J. P. Schadé and W. H. McMenemey (Eds.), Selective Vulnerability of the Brain in Hypoxaemia, Davis, Philadelphia, 1963, pp. 63-78.

4 Barlow, C. F., Domek, N. S., Goldberg, M. A., AND Roth, L. J., Extracellular brain space measured by S-35 sulfate, Arch. Neurol. (Chic.), 5 (1961) 102-110.

5 Barlow, C. F., Schoolar, J. C., AND Roth, L. J., Distribution of carbon-14 labeled isoniazid in brain, Neurology (Minneap.), 7 (1957) 820-824.

6 Barlow, C. F., Schoolar, J. C., and Roth, L. J., An autoradiographic demonstration of the relative vascularity of the central nervous system of the cat with iodine 131-labeled serum albumin, J. Neuropath. exp. Neurol., 17 (1958) 191-198.

7 Coppen, A. J., Abnormality of the blood-cerebrospinal fluid barrier of patients suffering from a depressive illness, J. Neurol. Neurosurg. Psychiat,. 23 (1960) 156-161.

8 Craigie, E. H., Postnatal changes in vascularity in the cerebral cortex of the male albino rat, J. comp. Neurol., 39 (1925) 301-324. 
9 Davson, H., A comparative study of the aqueous humour and cerebrospinal fluid in the rabbit, J. Physiol. (Lond.), 129 (1955) 111-133.

10 Davson, H., AND SPaZiani, E., The blood-brain barrier and the extracellular space of the brain, J. Physiol. (Lond.), 149 (1959) 135-143.

11 Dobbing, J., And Sands, 3. A., The entry of cholesterol into rat brain during development, J. Physiol. (Lond.), 166 (1963) 45P.

12 Donahue, S., And Pappas, G. D., The fine structure of capillaries in the cerebral cortex of the rat at various stages of development, Amer. J. Anat., 108 (1961) 331-348.

13 Everett, N. B., Simmons, B., ANd LASHer, E. P., Distribution of blood (Fe $\left.{ }^{59}\right)$ and plasma ( ${ }^{131}$ ) volumes of rats determined by liquid nitrogen freezing, Circulat. Res., 4 (1956) $419-424$.

14 Globus, J. H., AND KUHLENBECK, H., The subependymal cell plate (matrix) and its relationship to brain tumors of the ependymal type, J. Neuropath. exp. Neurol., 3 (1944) 1-35.

15 Grazer, F. M., and Clemente, C. D., Developing blood-brain barrier to trypan blue, Proc, Soc. exp. Biol. (N.Y.), 94 (1957) 758-760.

16 Himwich, H. E., AND Himwich, W. A., The permeability of the blood-brain barrier to glutamic: acid in the developing rat. In H. WAELSCH (Ed.), Biochemistry of the Developing Nerious System, Academic Press, New York. 1955, p. 202.

17 Kapp, J., ANI PAulson, G., The nature of the cerebrospinal fluid-brain barrier and its response to circulatory arrest. I. The effect of circulatory arrest on the movement of cerebrospinal fluid sodium into brain, Neurology (Minneap.), 17 (1967) 720-723.

18 Katzman, R., Effect of electrolyte disturbance on the central nervous system, Ant. Rev. Med., 17 (1966) 197-212.

19 Katzman, R., ANd Leiderman, P. H., Brain potassium exchange in normal adult and immature rats, Amer. J. Physiol., 175 (1953) 263270.

20 LAJTHA, A. Amino acid and protein metabolism of the brain. II. The uptake of L-lysine by brain and other organs of the mouse at different ages, J. Neurochem., 2 (1958) 209-215.

21 LAL, H., BARLOW, C. F., AND ROTH, L. J., Barbital. $\mathrm{C}^{14}$ in cat and mouse, Areh. int. Pharmacodyn., 149 (1964) 25-36.

22 MCLennan, H., Diffusion constants in the extracellular space of brain tissue, Neurology ( Minneap.), 8 (Suppl, 1) (1958) 67-68.

23 Meyer, J. S., Gotoh, F., Ebihara, S., and Tomita, M., Effects of anoxia on cerebral metabolism and electrolytes in man, Neurology (Minneap.), 15 (1965) 892-901.

24 OlsEN, N. S., AND RUDOLPH, G. G., Transfer of sodium and bromide ions between blood, cerebrospinal fluid, and brain tissue, Amer. J. Physiol., 183 (1955) 427-432.

25 PHelps, C. H., An Ultrastructural Analysis of the Development of Capillaries and Associated Neurologia in the Spinal Cord of the Rat, Ph. D. Thesis, University of Michigan, 1966.

26 Quastel, J. H., Molecular transport at cell membranes, Proc. roy. Soc. B, 163 (1965) 169-196.

27 Reed, D. J., Woodbury, D. M., and Holtzer, R. L., Brain edema, electrolytes, and extracellular space. Effect of triethyl tin on brain and skeletal muscle, Arch. Neurol. (Chic.), 10 (1964) 604-616.

28 RoTH, L. J., AND BARLOW, C. F., Drugs in the brain: autoradiography and radioassay techniques permit analysis of penetration by labeled drugs, Science, 134 (1961) 22-31.

29 TsChirgl, R. D., Frost, R. W., AND TAYlor, J. L., Inhibition of cerebrospinal fluid formation by a carbonic anhydrase inhibitor, 2-acetylamino-1,3,4-thiadiazole-5-sulfonamide (Diamox), Proc. Soc. exp. Biol. (N.Y.), 87 (1954) 373-376.

30 Vernadakis, A., AND WoOdBuRY, D. M., Electrolyte and amino acid changes in rat brain during maturation, Amer. J. Physiol., 203 (1962) 748-752.

31 Vernadakis, A., AND WoOdbury, D. M., Cellular and extracellular spaces in developing rat brain, Arch. Neurol. (Chic.), 12 (1965) 284-293.

32 WISLOCKr, G. B., AND Leduc, E. H., Vital staining of the hematoencephalic barrier by silver nitrate and trypan blue, and cytological comparisons of the neurohypophysis, pineal body, area postrema, intercolumnar tubercle and supraoptic crest, J. comp. Neurol., 96 (1952) 371-413.

33 Woodbury, D. M., Discussion. In W. F. WIndee (Ed.), Biology of Neurologia, Thomas, Springfield, Ill., 1958, p. 120. 